\title{
日本輸血学会九州支部会 第13回総会・第24回例会
}

日時 昭和 41 年 5 月 28 日

場所 福岡市三鷹ホール

支部長 九大医学部教授 井口潔 会 長 九大医学部教授 古川 哲二

1）不適合輸血の経験

大分赤十字病院外科

○清水 力・平塚 弘之

野松 潯一・染矢 周一

2）出血性素因患者に対する体外循環の経験 九大西村外科

西村 正也・飯田 順造

大里 敬一・林村誉司

3） A C D 血体外循環の基礎と臨床

$\mathrm{Ca}$ の適正使用量について

\section{長大辻外科}

○秋山 寿男 - 田崎 亟治・富田 正雄 •

麻生 弘之・古賀 保範・釘宮 敏定・

伊福 真澄・山口洋一郎・木戸 正之・

大林 協治 - 田中 耕三・馬場 尚道・

安中 正道

4）ＡＢＯ型不適合児に対する合成血による全

血交換 3 例

九州厚生年金病院産婦人科

松木英一郎・本田 義弘・O富岡常泰

5）血清肝炎罹患患者の臨床的検討

九大井口外科 池尻 泰二・倉重 正敏 九大中央手術部 ○山口 国行

6）輸血後肝炎特に発生率の年次推移について 長大辻外科

田崎 亟治・ O田中 尚・山口洋一郎・

牵田 博夫

化血研長崎血液銀行 島田 勝良

7）体外循環症例の血清肝炎発生率について

\section{久大古賀外科}

古賀 道弘・正木 秀人・大石 嘉六 ○高木 博已・加来 信雄・吉田 晃治

8）薬剤による血清肝炎予防の試み

九大胸部疾患研究所

大田 満夫 - ○広田暢雄・矢野 国枝・ 児玉 武子

9）自家血輸血の経験

北九州市立松寿囷外科

○芥川 光男・户叶 栄一。

貝原 信明

10）輸血節減に関する実験的臨床的研究

国立福岡中央病院外科

楠卓郎・下野 亮介 九大胸部疾患研究所 大田 満夫

九大井口外科 野見山 保

11）マンモス献血の経験

大分県赤十字血液センター

大分赤十字病院外科 $\mathrm{O}$ 清水 力

佐賀関製鍊所病院 香川 哲夫

総会

パネルデイスカッション(献預血推進の問題点)

(15. 30-17.00)

司 会 古川 哲二

1. 献預血使用の臨床的意義

九大井口外科 池尻 泰二

2. 九州地区における輸血の現況

福岡県薬務課 尾崎 松夫

3. 我国における献血の問題点

福岡日赤血液センター 吉成 意之

4. 鹿児島に抢ける献預血推進状況

鹿児島化血研 平石 幸作

発言

長大辻外科 田崎 亟治 
熊大吉永外科 中村 良昭

久大古賀外科 古賀 道弘

福岡県医師会 斉藤 辰己

\section{一般演題}

\section{1）不適合輸血の経験}

大分県赤十字病院外科

○清水 力・平塚 弘之・

野松 憲一・染矢 周一

われわれは, 最近, $\mathrm{A}$ 型の63才の男 (胃潰瘍) にB型血液200ccを，また，B型の55才の女(乳癌) にA 型血液. 200ccを誤って輸血した．前者では症 状が軽く，後者ではショック状態になったが，い ずれも適切なる処置により，回復せしめえた．前 者ではその後胃切除術を, 後者では乳房切断術を 施行したが，現在良好な経過をたどっている．わ れわれの苦い経験を開陳し，いささか文献的考察 を加えながら，不適合輸血の起こりらる原因につ いて反省を試みた。

\section{2）出血性素因患者に対する体外循環の経験}

九大西村外科

西村 正也・浅尾学・飯田 順造・

○木村 誉司・大里 敬一・吉成 意之

出血性素因を有し，心室中隔欠損を伴う高度の 肺動脈漏斗部狭窄の先天性心疾患患者を, 術前に 十分 control 乙, 術中・術後の適切なる処置によ って順調な経過をとったので報告する。（1）術 前の出血傾向は凝固学的治療で control できた.

（2）術中から術後にかけての出血時間延長は血 小板数の回復に比べ，かなり遅延した。（3）体 外循環中の線溶現象元進拉よびフイブリノーゲン の軽度減少がみられた。（4） plasma-heparinの 緩徐な減少は第14回日本輸血学会総会で発表した

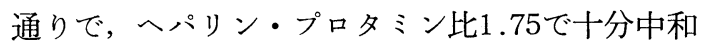
され, 術後 heparin-rebound 現象に上る出血増加 はなかった。（5）術後出血量は $10.4 \mathrm{ml} / \mathrm{kg}$ で, 他の一般症例と変りなかった。（6）開心術に は, 血液凝固学的検查を十分に行ない, 術中, 術
後の意外な出血傾向を防止する上に，出血性素因 の有無を確めることが必要である．症例の如き出 血性素因疾患でも適切なる管理の基に開心術を施 行しらる。

3） ACD 血体外循環の基礎と臨床, $\mathrm{Ca}$ の適正 使用量について

長大过外科

○秋山 寿男・田崎 亟治・富田 正雄・ 麻生 弘之・古賀 保範・釘宮 敏定・ 伊福 真澄・山口洋一郎・木戸 正之・ 大林 協治・田中 耕三・馬場 尚道・ 安中正道

従来より，体外循環には主としてへパリン加新 鮮血が用いられているが， ヘパリン加血は保存能 が低い事をはじめ，幾つかの不利な点を有する。 かかる種々の制約を除くために，保存能の優れた A CD血を Disc type 人工心肺による開心術に 利用できれば有利であると思われるが，AＣD血 急速大量注入に伴う Cardiovascular Collaps 著 しい代謝性 Acidosis などがあって安全性に欠け る.われわれは，このよらな A C D血を，体外循 環に利用可能ならしめるために, イヌでA C D 単 独群, A C D + T H A M群, A C D + Ca 群の 4 群について注入および体外循環実験を行なった。 A C D 血 250cc当り10mgのヘパリン添加後 Buffer Deficitに対するTHAMとA C D 液 $100 \mathrm{cc}$ 当り 350mgの Ca を添加し，軽度低体温下に行なえ ば，A C D 血体外循環は極めて安全な事を確認し たので, 臨床例 6 例に実験時と同一方法でA C D 血体外循環を行なったところ，血行動態，酸塩基 平衡, 電解質, 心電図上からもへパリン加血使用 群と差を認めず, さらに, 血球数, 溶血度, 出血 時間, 凝固時間などでは優れた成績がえられた。

質問国立福岡中央病院外科下野 亮介

1） A C D血は, 採血後, 何日以内のものを使 用しているか。

2）充填血 3,000 ccの外に 何か希釈液を使用し ているか.

長大辻外科 秋山 寿男

1） A C D 血は，開心術の前日の午前中に採血 
し，つぎの日の午後 1 時から使用しているが，採 血後 4-5 日までのAＣＤ血であれば，Disc Type 人工肺による体外循環に利用できると考えてい る。

2）充填血の希釈には，レオマクロデックス， P V P， マニトールを主として希釈しているが， 体外循環開始直後の $\mathrm{Ht}$ が33\%程度になるように 計算して希釈している.

\section{4） ABO 型不適合児に対する血漿置換合成血}

\section{による交換輸血}

九州厚生年金病院産婦人科

松木英一郎・本田 義弘・O冨岡 常泰 新生児溶血性疾患の原因として, 母児間血液型 不適合があげられるが, 私どもは, A B O型不適 合児 3 例に対し, 血浆置換合成血で交換輸血を行 ない，良好な結果をえた。

血将置換合成血は簡便法で作成した。すなわち 採血後 7-10日間静置した 0 型保存血からできる だけ多くの血浆を除き，A B 型保存血より同様に して採った A B 型血浆を加元, 凝集原, 凝集素の ない血液を作成した。

その際, 加える A B 型血浆は, 除いた 0 型血浆 より10-15\%少くして血液濃度をあげ，その500600 ccを使用した。

手技は，Diamond 法，または，Pinkus 法で行 ない, 1 回40cc，5 分以上で輸血し，1 分間休止 して，5-10分で瀉血を行ない， 3 時間前後で終 了した。

このうち 1 例は術後貧血がひどかったため, O 型血液 $40 \mathrm{cc} の$ 再輸血を行なった。

\section{追加九大医学部産婦人科 久永 幸生}

九大産婦人科教室においては1955年, 教室相原

・松隈によって, すでに, 発表されている如く,

B 型 $\mathrm{Rh}(-)$ 血に対し $\mathrm{O}$ 型 $\mathrm{Rh}($ （）とA B 型 血浆による血浆置換合成血の使用が最初である.

その後, A B O式血液型不適合による新生児溶血 性疾患に対して, 教室橋本の詳細な検討がある.

1951年から 現在まで16 年間交換数 167例のう ち，血浆置換合成血を使用したもの81例を数えて いるので追加する.

\section{質問 九大医学部産婦人科 久永 幸生}

1）第 1 例は, anemic form といらことである が, anemic form は新生児溶血性疾患の最も軽症 型であり, 交換輸血の適応とは考兄難いが如何に 考えられるか。

2）交換輸血は，その方法が使用血管の数にか かわらず，理論的にも実験的にも 100\%の交換率 はえられない，演題に全血交換といわれるのは, 交換率上昇のために何か特別な配慮をなされた か.

答 九州厚生年金病院産婦人科冨岡 常泰

1）前回分娩児で交換輸血を行なっており，家 族からの強い希望もありましたので, 社会的適応 を幾分加味しまして早目に行ないました。

2）とくに，そのようなことはおこなっており ません，演題は，“A B O型不適合児に対する血 浆置換合成血による交換輸血”之変更いたしま す.

\section{発言厹大医学部麻醉科 古川 哲二}

先日, 新聞紙上で, 腹腔内の胎児に輸血された のを拝見しましたが，その時の様子を扣話しいた だければ有難いと思います。

\section{発言 九大医学部産婦人科 久永 幸生}

胎内輸血：われわれの施行した症例は, Od. 6 回経妊の妊婦であり, 前回妊娠は妊娠32週で, 新 生児溶血性疾患の最も重症な Hydropic form で 死産しており, 今回妊娠も妊娠中抗体価32倍と高 く, amniocentesis により児死亡の危険性が極めて 強いため, 胎児腹腔内に $\mathrm{Ht}$ 值を $72 \%$ に上昇した 血球泥75ccを輸血したものである．胎児腹腔内に はX線テレビを使用し, 胎児腹腔内にカテーテル を挿入して輸血を行なったものであり，胎内交換 輸血とは異なるものである。

\section{5）血清肝炎罹患患者の臨床的検討} 九大医学部井口外科

池尻 泰二・倉重 正敏 九大中央手術部 ○山口 国行

最近発生率を減じたとはいえ,な敃輸血例の 1 $2 \%$ に発生をさけえない血清肝炎症例が，ど のような経過を辿るかについて, 昭和38年度以降 
の発黄例20例および非黄疸型 5 例, 計25例につい て，臨床的調査を行なった，症例は $40 \%$ が $1000 \mathrm{ml}$ 以内の輸血量であり, 最短 17 日, 平均 2 力月前後 の潜伏期をむって発黄しているが，発黄または， トランスアミナーゼ值上昇に先立って症例の半数 に食思不振あるいは全身倦怠を訴えた．25例につ きトランスアミナーゼ值の follow upを含めて, その転帰をみると，慢性肝炎移行例 2 例 $11 \%$, 朋炎死亡 1 例 $6 \%$ ，その他 $83 \%$ は一応一次的に治 癒したものと考えられる。慢性肝炎症例の中, 1 例は僅か $400 \mathrm{ml}$ の輸血量で発症し, 死亡例は, 肝炎発生後, 終始大学病院で十分な観察期間・薬 治療法をらけながら不幸な転帰をとったもので あって, これらの症例を省み，さらに完壁な予防 対策が緊急事であると痛感された。

6) 輸血後肝炎, 特に発生率の年次推移につい $\tau$

長大医学部辻外科

田崎 亟治・ O田中尚・ 山口洋一郎・牟田 博夫 化血研長崎血液銀行 島田 勝良 われわれの教室における輸血後肝炎発生の年次 的推移は，38年度 $43.0 \% ， 39$ 年度 $51 \% ， 40$ 年度前 期（40年 4 月- 40 年 9 月），35.6\%，40年度後期 40 年10月- 41 年 3 月), $18.5 \%$ であった。発黄率は いずれも大差なく，3.5\%前後であった。これら の年代の献預血之職業血の占める割合をみると， 38年度, 39年度がほとんど, 職業血で占められて いたが，40年度より，Family donor の動員で， 献預血が80\%以上を占めるようになってきた。つ ぎに 40 年度後期の輸血後肝炎の現況を述べ，とく に本年度は初発期間が 2 週間の肝炎がかなりある 事を述べた．治癒期間は短縮されているが，なお 少数ながら再発型・慢性型があり, 輸血後肝炎の 予防対策が重要であり，そのスクリーニングの 1 つとして初生ヒナ血球凝集試験を行ない, 施行群 では肝炎発生率が $15.1 \%$ ，非施行群では，26.5\% と好成績をえた。

追加社会保険小倉記念病院 手島 宰三 当院は, 中程度の病院で, 脳神経外科は新設さ
れたが，心臓外科は施行していない。

37年度は $18 \%$ といら恐るべき発生率であった が，38年度激減し，再び増加しつつある。

輸血量の年次・月次推移と昭和 40 年度輸血後肝 障害症例を示めした。非輸血術後黄疸例が 3 例あ る（上腹部消化管胆囊胆道手術は除く）.

輸血後肝障害症例の中には輸血因子以外の因子 による肝障害が少数ながら混在していることをか 朊てから主張してきた。

\section{7）体外循環症例の血清肝炎発生率について}

久大医学部古賀外科

古賀 道弘・正木 秀人・大石 嘉六・

○高木 博己・加来 信雄 $\cdot$ 吉田 晃治

当教室に打ける昭和 35 年 6 月から昭和 41 年 2 月

までに，人工心肺を使用して先天性および後天性 心疾患に対して行なった手術の結果, 現在生存し ている 152例中 149例を対象として術後血清肝炎 の発生率を検討した。

全症例に対する血清肝炎発生率は，149例中21 例， $14.0 \%$ ，その内黄疸発生をみたものは11例， $7.3 \%$ であった. 残り10例は, GOT・G P T 值 の上昇のみで黄㾝発生は観察できなかった．年令 別では年長になるほど，発生率は高く，男女性別 では差なし，血液型別では，O型，A型に多く， 輸氐量では明確な傾向はなかった。疾患別では, 症例数の多い. A S D・V S D に黄疸発生数が多 かったが，特別関係はなかった。

また, 黄疸発生例は, 血清肝炎発生時, 肝障害 が，強く出現していた。

なお，献血の問題には言及しなかった。

8）薬剂による血清肝炎予防の試み

九大胸部疾患研究所

大田 満夫 ・ ○広田 暢雄・ 矢野 国枝・児玉 武夫

私どもは術後の血清肝炎発生を予防する目的で Inosine: Hypoxanthine riboside (HXR) 拈よび Protoprophyrin-Na などの薬剤を, 胸部外科手術 例に使用し，血清肝炎の発生に予防的効果がある かどらかを検討した．胸部手術例の肝機能成績の 内GOTの值の経過をHXR使用の 9 例について 
見ると G P T が 100以上になった症例はなく，術 後, 追跡期間の短かい症例もあるが, 退院後黄疸 発生例は認められなかった。

Protprophyrine-Na 使用の19例では同時期に 同様の胸部手術をらけていたにも拘らず G P T 100 以上の術後肝炎が 6 例発生し, 発生率 $31.6 \%$ であった，当所の胸部手術後の肝炎発生率は昭和 33年度より39年度までは， $32.7 \%-45 \% ， 38$ 年 1 月より 40 年 4 月までに，輸血を伴う胸部手術をう けた214例では41\%であった. 肝機能障害例および 自他覚的に肝炎を疑われたものへのHXRおよび Protoprophyrin-Na の投与は治療効果があるよう に思われる症例もあったが, 輸血後肝炎の発生を 予防する効果はHXRにあるよらに考えられた。

追加・質問 朝倉郡太刀洗病院 森重 福美

1）追加：私の施設における千数百例の輸血例 を6カ月から 1 年以上 follow up した自験例で 発黄型のものは, 数例にすぎない. トランスアミ ナーゼ上昇例はしばしばあるが，ブドウ糖 1 日量 $50 \mathrm{~g}$ を中心する肝庇護剤の投与で大部分の例が トランスアミナーゼ值が正常化する. 中止後再び 上昇する例も治療を繰返すことで好転する。

2）質問：いわゆる輸血後肝炎から肝硬変に移 行する例は肝炎発生率に比して少ないと思らが， 生検で確認した例はあるか。肝は組織再生の旺ん な蔵器の 1 つであり, 肝炎の大部分はよくなるも のであり, 肝硬変に移行するようなものは殆んど 重篤な肝炎経過で死亡するのではないかと思われ るが。

発言・答弁 九大胸部疾患研究所 大田 満夫

当所では血清肝炎死亡例もあり，また遷延化す る事も流行性肝炎より多い上うであり，血清肝炎 は現在でもな叔重大なものと考光ます。

慢性化( 6 カ月以上G P T 100以上)した症例で は, 血清膠質反応に異常がみられる事が多くなり， 将来, 肝硬変になる恐れがあるものと考えます。

九大胸研の術後肝炎発生率が高いのは, 胸部手 術で輸血量が多い事, 術前結核化学療法が長い事 にもよると思いますが，術後確実に肝機能を追跡 できるため，無黄疸性肝炎も洩れなく見出しらる
ためでもありましょら

発言社会保険小倉記念病院手島 莘三 最近の輸血後肝炎の予後に関して：最近の輸血 後肝炎症例では予後が良好である。例えば，社会 保険病院におけるアンケートによる統計によれば 肝硬変死亡例は無い。しかし，䀒炎が遷延して旰 硬変になったと考えられる症例が，無い訳ではな い.日本内科学会において,この問題に関し結論 を出し, 輸血後肝炎が肝硬変に移行し予後が悪い ことを警告している. 外科医の短期間, 比較的少 数例による推論は危険であろう. 当院においても 肝炎が遷延し，肝硬変になったと思われる症例が ある．予後が良いと思われても肝庇護に有効と思 われる方法・薬剤は十分に施行し, 肝炎が治癒し たと思われても, その後 2 力月は安静保持・経過 観察すべきである。

\section{9)自家血輸血の経験}

北九州市立第二松寿園外科

○芥川 光男・戸叶 栄一 - 只原 信明

われわれは, 手術の 2 週間前と 1 週間前に, そ

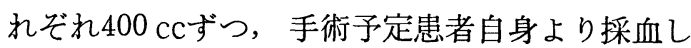
た血液を，手術時に用いている。

40 年 9 月より 41 年 5 月までに肺切除54例に施行 しそのらち32例(全滴 3 例を含む) は自家血のみで 手術を行なった。採血前, 赤血球の最も少ないも のは350万血色素の最も少ないものは70\%で，手 術中出血量は最大 $1350 \mathrm{~g}, 27 \mathrm{~g} / \mathrm{kg}$ であった.

術後の赤血球・血色素は無輸血の場合より変動 が少なく，減少の程度が軽度であった。また， 無輸血例, 銀行血例と比較して, 術後の B S P • GOTの值は, 平均上昇率でみても, 異常值の 出現率でみても, 自家血輸血例が最も小さく, 肝機能の影響が最も少ないと考えられる.

\section{発言九大医学部麻酔科 古川 哲二}

福岡県薬務課・尾崎松夫課長へ.

採血は，1回 200ccまでとさいておりますが， これは法的にきめられたものでしようか。

発言福岡県薬務課長 尾崎 松夫 採血量の制限について。

採血量については法的規制はありません。しか 
し献血は，はじめから 200cc 1 本採血できてい ます。

民間血銀も従来 $400 \mathrm{cc}$ 採血していましたが，本 年 4 月より $200 \mathrm{cc} 1$ 本採取に自肃採血いたしてお ります。

\section{0）輸血節減に関する実験的臨床的研究}

国立福岡中央病院外科

九大胸部疾患研究所 卓郎・下野 亮介

大田 満夫・监玉 武子 九大医学部井口外科 ○野見山 保

血液の不足が，社会的に大きな問題となりつつ ある現在, 外科手術, 特に大量の血液を必要とす る開心術に打ける血液節減は, 早急に解決されな ければならない。われわれは，5\%糖液，10\%糖 液, 高分子および低分子デキストラン, 生理食塩 水, E L 3 号, ヘマセル, スーパーミンプラスを 使用して, 種々の脱血, 注入, 置換実験を行ない さらに，その結果を応用して，つぎのような結果 をえた。

1） Plasma Expander のみの性質からは，スー パーミンプラス, デキストラン, ヘマセルが優れ ている。（2）電解質からみると, 生理食塩水, ヘマセルがよい（3）排泄の点からみると, 10\%糖液， Nacl 液がよい。

以上の点より, 無血充填液の特性を考慮すると， 2-3 種類の液の組合せを行なら必要があり臨床的 に, 低分子デキストラン 1 にリンゲル液 1, これ に20\%マンニットール添加ならびに, $\mathrm{NaHCO}_{3}$, lactate を混合した充填液が，現在のところ最も よい結果をえている。

\section{1）マンモス献血の経験}

\section{大分県赤十字血液センター 大分赤十字病院外科 ○清水 力 佐賀関製錬所病院 香川 哲夫}

最近，商業血液銀行の採血量が，200 cck規制 されたため, 売血者が減少, 商業血銀保存血液量 の急速な激減をみている。黄い血液追放としては 結構な事ではあるが, 未だ献血預血が需要血液量 の大半を占むるに至らない現況下では, 血液の需
給に困惑している．保存血零のため手術の予定が たたない場合もあるといら最悪の状態になりつつ ある。

われわれは，この度，日鉱佐賀関製錬所の協力 によりマンモス献血の成功をみたが，暗い血液事 情に光明をもたらせたものと考えている.

大分県下では一般に事業所や官公庁に怙ける献 血の成績は残念ながら余り香ばしくないが，今回 のマンモス献血は真に劃期的なものと考光ている ので, その成功の原因を考察し，今後の献血推進 のあり方の参考に供したい.

発言.九大医学部麻醉科 古川 哲二

佐賀関製錬所におけるマンモス献血は，向後も つづけて施行される所存ですか.

$$
\text { 大分県赤十字血液センター }
$$

答 大分赤十字病院外科 清水 力

今回のマンモス献血は第 1 回目ですが，引きつ づき第 2 回, 第 3 回の献血を施行する予定です.

\section{パネルディスカッション}

\section{献預血推進の問題点}

司会杂大医学部教授 古川 哲二

\section{1）献預血使用の臨床的意義}

九大医学部井口外科 池尻 泰二

血清肝炎発生率といら面から献預血使用の意義 を検討した結果は以下のごとくである.

1）九州大学附属病院全体として, 家族供血を 中心とした職業血排除に努力した結果, 昭和 40 年 の 1 年間で, 毎月血液使用量の大凡 8 割を献預血 血液で占めるようになった。

2）その結果をふり返ってみると，井口外科の 症例については, 従来 (昭和37年度) 黄疸型肝炎 発生率が $6.8 \%$ であったものが，昭和 39 年 6 月一 40 年 5 月では, 肝炎発生率 $1.7 \%$ と率を減じ, 特 に献預血血液のみ使用の 297 例では，0.7\%の低率 であった。

3）これを九大病院全体の成績で見ると, 従来 
ほとんど職業血のみに頼っていた時期の血清肝炎 (黄疸) 発生率 $7.1 \%$ (科によって, 3.6-11.8\%) から, 最近の 995例中 $3.5 \%$ 亿発生率を減じ, 特に献預血血液のみ使用の 573 例では， $1.9 \%$ の低率であった。

4）今日までの経験で今後問題点として残され る所は(1) 献預血血液を使っても, 職業血を併用 すると相変らず発生率が高く, この点各症例ごと に売血混入を防ぐ監視が大切なこと。（2）献預 血血液使用では全体として血清肝炎発生率が低い のではあるが, 各科別のデータをみると, 10\%近い 高率の肝炎 (黄疸) 発生を見ている科もあること.

（3）黄疸発生は少なくてもトランスアミナーゼ 異常上昇の頻度 は, 献預血でもかなり高いとい ら科もあること。（4）献預血血液による発黄例 からふりかえって見て，一般献預血者中の silent carrier の存在に大いに気を配るべきこと，など である。

しかし，これらの諸点を今後の問題として残し てはいても, 血清肝炎防除の点で全体として献預 血血液が売血に比して有利なことは間違いないよ らであり, 今日の問題は, むしろいかなる具体策 をもって献預血を早急に推進するかにある。

\section{2）九州地区における輸血の現況}

福岡県薬務課長 尾崎 松夫

まず昭和40年の九州における血液の需給状況を 申し上げますと.40年中に抢ける九州の血液の需 要量は 241,562 本 $(48,312 l) て ゙$, 製造されたもの が 246,808本 $(49,361 l)$ で, 需要量に対して 102.17\%で，僅かに製造量が需要量をオーバー している状況であります。 その内訳は需要量以上 の生産をしているのは福岡と熊本の 2 県で, 大分, 鹿児島, 宮崎, 長崎, 佐賀の 5 県では不足で, 福岡, 熊本の 2 県から賄っていた。 その状況も 福岡県よりの補充が 44,401 本 $(8,880 l)$ 熊本 県よりの補充が2307本 $(474 l)$ となっている.

九州に打ける製造量の内訳を見すすと

製造量 246,808本 $(49,361 l)$

売血 160,103 本 $(32,020 l) \quad 66.28 \%$

献血 57,049 本 $(11,409 l) 23.62 \%$
預血 29,655 本 $(5,931 l) \quad 12.28 \%$ 需要量の $102.17 \%$

つぎに, 41 年の状況をみると,まず1-3 月までの 3 カ月に製造されたものが69,318本 $(13,943 l)$ で, 41 年の九州各県の需要量の見込は, 年間 261,075 本 $(52,215 l)$ で，昨年の 8.7 増で，これより 見ますと $1-3$ 月までの 3 カ月の平均需要見込量 65,268 本 $(13,053 l)$ に対し，実際製造されたも のが69,718本 $(13,943 l)$ で，昨年同様僅かに製 造量が需要量をオーバーしているわけであります が，4月になりますと民間血銀の売血の 200cc 1 本採血を厳守いたしました結果，売血による製造 量が急激に減少いたしましたので，従来に比して 売血は $39.36 \%$, 月 4,499 本と約 $1 / 3$ となって参 り, これに反し

$\begin{array}{lll}\text { 献血 } & 113.69 \% & 7,774 \text { 本 } \\ \text { 預血 } & 183.90 \% & 8018 \text { 本 }\end{array}$ 計 20,840 本の従来製造量の $89.68 \%$ と約 $10 \%$ 強減 となっております。

需要量に比して見ると 4 月の実績は, 需要量平 均月 21,756 本 $(4351 l)$ 飞対し, 製造量は20,840 本 $(4168 l)$ で95.3\%で, 僅かに1116本 $(223 l)$ の $4.3 \%$ 減となっている.

福岡県の場合は，4月の実績は平均需要量月間 9200本 $(1840 l)$ に対し9716本 $(1943 l)$ の製造 で $105.6 \%$ となっている. しかし，従来の生産 量と比較すると2274本減の $18.97 \%$ 減となってい る。しかしその内訳は，

売血 8882本

預血1730本 $14.44 \%$ 計 11993本

献血1388本 $13.88 \%$ であったのが，

壳血 3068本

預血 2835本

献血2816本 $\left.\begin{array}{l}31.56 \% \\ 39.44 \% \\ 29.00 \%\end{array}\right\}$ 計9719本 となっている。

現在までの状況では，量的にはどらにか間に合 っているが, 型別需要の面から実際の要求に対し て賄らことができない状況で，特に従来売血主体 で賄われていた本県の場合, 筑後の久留米, 大牟 
田地区において血液不足の声が強く, 今後の見通 しとして，さらに売血は急激に減少するものと思 われるので，よほどこの減少を賄うに足る献血， 預血が伸ばない限り, 次第に血液不足は深刻とな るものと思われますので，このさい大いに献血， 預血を推進しなければならないことを加えて報告 いたします。

\section{3）鹿児島における献預血推進状況}

\section{鹿児島化血研 平石 幸作}

本県では現在, 90\%から 100\%県内需給の献預 血をもって輸血が行われていることは, 毎週定期 的に行われている南日本放送と県民の協力による ものである.

全血比重と $\mathrm{Hb}$ の精検を市内普通高校生 512 名に行なったが，両者ともに基準以下のものが 13 名あり，比重のみの不足は一般人と同様に約30\% であり，これは健康管理上,採血に注意を要する.

血清肝炎は 2 力年間の本県の献預血推進ととも に, 3.8-3.3-2.1\%と減少し, GOT, G P T 合格血輸血では $0.9 \%$ 発生率である.

本県の根本的血液対策は, 献預血をもって行な らことを本命と当局および県医師会で決定し, ま た離島や血液不足の急場にそな光医師会で $\mathrm{Rh}$ 型を含む血液をすでに13万人登録している．沖緡 の患者が多いため, これらの人に要する新鮮血を 県民で行ない，その分を沖縄からの保存血輸入で 補い度き切実な要望がある。

採血場より採血車, 採血船の増加が各方面から 切実に訴えられている。

血液不足のため 診療能率の 低下を防ぐために は, 当局も日赤も血銀の医療機関も 1 団となって 県民 1 人 1 人が納得できるような受入態勢が必要 である。

\section{4）我国における献血の問題点}

福岡県赤十字血液センター 吉成 意之 売血代1000円の魅力が $200 \mathrm{cc}$ 自肃採血と共に 売血者になくなった，商業血銀の預血は，見舞金 500円の魅力をもって従来の買血本位制度維持の ための一時的支えとなっている. しかし一方わが 国の血液事業は日赤および都道府県による献血推
進一本立でゆく方針が閣議決定(昭和39．8．21) されて以来, 昨年で血液センターのない県はなく なり，全国的に献血運動は盛り上ってきていた。 それに，血液不足に直面した医療機関の積極的協 力と家族供血（指定献血）のやむなき人々の参加 もあって, 献血運動の進展は急速になった。これ に応じて血液センターは献血希望者へのサービス 改善のために受入れ施設の増設と内容の充実に努 めている。また配給業者側や使用者側に献血尊重 の心構えを訴えている。な挌各自の循環血液量に 対する理解を深めるよう教育的 P Rを行なってい る.最後に，先進国の血液事業が 100\%献血でな されていること，その好例としてオーストラリア を紹介した。

\section{発言長崎大学辻外科 田崎 亟治}

昭和39年後より教室でも血清肝炎予防対策の一 環として family donor の動員に力を入れ，40年 4 月より 41 年 3 月まで使用血液中 $83.5 \%$ は預血に よっている。一方長崎県下全般（佐世保地区を除 く）についてみると，40年では献血 $18.6 \%$, 預血 $11.9 \%, 41$ 年では献血 $10.0 \%$, 預血 $34.4 \%$ となっ て売血追放にとって一見好ましい傾向にある如く 見受けられる.しかし，その内情は39年10月頃より 売血採血量が減少し，しかも献血量の増加は見ら れず, 殊に本年 4 月以降は血液不足が著しく, 血清 肝炎の予防としてょり, むしろ血液需要量確保の ためのfamily donor の動員が大学を除く他施設に も普及しつつあるが，な和救急患者・採血施設に 遠い病院では, 昔に戻って枕もと輸血が行なわれ ている現況にある. 今日の血液不足・売血追放に 対処する為には, 常識的ながら献血のための P R の普及・採血車・採血施設・人員の 増加・商業 銀行を公益銀行に変更する. 離島採血などの財政 的裏づけをもった国家の積極策が必要である。ま た今日の預血はいわゆる family donor の動員に よる指定預血であるが，この形を 1 歩すすめて一 定量の預血者には必要時還元するといった法をも 検討するなど, 今日単に人類愛に頼る献血法を早 急に再検討すべき時期にきていると考えている． 
発言 熊本大学吉永外科 中村 良昭

1）全血比重に関して：熊本日赤の資料によれ ば，献血合格率は男90\%，女54\%となり，男性に は地域差は少いが，女性には合格率も低く，地域 差も多い.

吉永外科に入院した患者の中から良性疾患で自 覚症が少なく，入院前日まで通常の生活を営んで いた症例 280例を選び $\mathrm{G} \mathrm{B}$ と $\mathrm{RBC}, \mathrm{Hb}, \mathrm{Ht}$ との 関係をみたところ $\mathrm{G} \mathrm{B}$ は $\mathrm{Hb}$ と最も相関性があ りしかも 1,052 以下になると $\mathrm{Hb}$ 女 $80 \%$ 割 ることが示されました，供血者の血液に $\mathrm{Hb} 80 \%$ を求めるとすれば， G B の基準を 1,052以下に下 ザることは，好ましくないようであります．

2）輸血節減に関して：外科の立場からいえ ば，輸血節減には 2 つの方法があります。その 1 つは，術中出血をなるだけ少なくする事で，吉永 外科の胃 ・十二指腸潰瘍に対する胃切除術の術中 出血量平均値の年次推移は昭和37年に $363 \mathrm{~g}$ であ ったものが年々減少し，昭和40年には $236 \mathrm{~g}$ にな っております．現在，良性疾患には輸血を絶対に しない方針で，術中出血量を最少にするよう努力 しています。

その 2 は，輸血そのものの節減であります．衰 弱高度のもの，急速に全身状態の改善を要するも の, 多量の血液を要するもの, 血液系疾患, 消化 器系疾患などは輸血節減が困難なこともあります が，その他の症例には貧血よりも低蛋白の治療に 主眼を拈いています。この中で消化器系疾患は， 術後経口栄養摂取が十分できないので，輸血を節 減した場合，慎重な術後管理が必要であります。 この場合でも, 創傷治癒の根本は $\mathrm{Hb}$ より蛋 白にあると考光, 術後, アミノ酸剂・脂肪乳斉 などを積極的に活用し，電解質の管理にも注意し ています，無論，術前は予測される輸血節減量に 応じて鉄剂とアミノ酸剤を与えています。

\section{発言}

福岡県赤十字血液センター 吉成 意之 女性の健康值の範囲は 1,050-1,054 であると いら調査結果をえている．法規に示された採血適 格の基準は 1,052以上となっているため不適格と
なる女性が少くない，その割合は平均 $20 \%$ にある ようである．農村婦人ことに山間部でこの比率が 50\%となった例があったが，これについては労働 に見合う栄養改善と休養の確保が望ましいと考え た. 平石博士の調査対象の中には鉄需要の高い年 頃の女子高校生があるので，比重不足の比率が一 般よりも高くなっていると考える。

男性の 正常範囲は1,054 - 1,058であるので, 1,052は比較的病的と考えて，法規では許されて いるが現在不適格として採血しない，その割合は 平均 $2 \%$ である。

発言 久留米大学古賀外科 古賀 道弘

久留米大学では本年 3 月まで輸血は大部分商業 血に依存していたが，4 月以降すべて献預血によ り輸血を行なっている．久留米に採血場がないた め, 献預血には福岡・小倉まで行かねばならず, 商業血に依存していた頃に比べ不便はまぬがれえ ない。

久留米大学における昨年 1 年間の血液使用量は 約 12,000 本, 月平均 1000 本で, 当教室の 1 か月間 の使用量は 400本で40\%を占めているが，使用量 の多い原因は主として人工心肺用の 新鮮 A C D 血，ヘパリン血が多く使用されるためである，4 月以降の使用量は人工心肺以外の保存血は昨年と 同数であるが, 人工心肺用の新鮮血は半数に減じ, 開心術の症例が減少している．輸血用血液の絶対 量の減少している現在, これに対処する方策とし て, 輸血節減が上げられる。一般手術では体重 1 $2 \%$ 出血までは輸血を行なわず 代用血浆を使用 し，人工心肺使用例では無血充填装置，あるいは 同一血型では 2 例連続体外循環などを行ない節減 に対処している.

人工心肺用新鮮血は一時に多量の同一血型の献 血が必要で, 種々困難な問題があるが家族・友人 などの努力により現在32件が献血されている．こ のためにはラジオ・新聞・テレビなどの P R が非 常に有効であった。

献血推進のためには，1）われわれ臨床家が患 者を通じて献血の必要性を徹底させ，これより大 衆に及ぼすこと．2）採血が容易に行なわれるよ 
うに採血車の増加・採血場の新設などを行ない, 採血網を作ること，と考える。

発言福岡県医師会副会長 斉藤 辰巳

最近，輸血の問題がむずかしくなってきたの で, 福岡県医師会では去る 4 月, 国公立病院を除 く全開業会員約2800名に対し，輸血に関するアン ケートをとった。

1） 5 月 27 日現在， $34 \%$ の回答があり，そのう ちで月 1 回以上輸血する医師は, 外科70\%, 婦人 科 $52 \%$, 内科 $20 \%$, 病院 $60 \%$, その他 $5 \%$ であ り，外科・婦人科および病院が主体である.

2）回答をよせられた医師の専門科別にみて も, 輸血に対する関心の所在を反映している。す なわち, 専門科別回答率は外科が $50 \%$, 婦人科が 35\%で，平均回答率34\%を上まわっている.

3）回答者の中で, 輸血用血液を必要とし（月 1 回以上輸血する人),かつ血液の不足を訴えてい る医師の割合を専門科別にみると，外科 $45 \%$, 婦 人科 $82 \%$, 内科 $70 \%$, 病院 $57 \%$ で, 婦人科・内科 が特に不足を訴える率が高い。これは日常血液銀 行などへのルートの問題など今後検討すべき点が 多いのではないか.

4）現在までの統計の整理結果より推定される 福岡県下の開業医師の使用する血液は年間総量は 約 $9,000 l$ 程度とみこまれ, 県衛生部の発表して いる県内の年間使用量 $22,000 l-25,000 l$ の $40 \%$ 以下である。

5）なお，つぎのような問題を目下検討中であ る.

a ）輸血用血液の入手困難を訴えている人は血 液銀行を利用しているかいないか，また新鮮血を 利用しているのか.

b ）血液銀行を利用しないで，生血を利用して いる人の輸血後肝炎の経験の有無

c ）売血使用と肝炎との関係

などである。

6）日赤の献血を利用するといら医師が全回答 者 970名中10例以下といら結果が出ているのは, まことに意外である。

7）別紙プリント（当日配布）は，血液不足に
対しての対策・意見についての回答をまとめたも のであって, いろいろと興味ある意見が出てきた ので,これをご紹介する。

8）昭和 41 年 5 月 26 日, 県下の都市医師会長会 議を開催し, 最近の血液不足につき献血預血につ いて協力方を要請したところ, 日赤の献血制度に ついていろいろと疑義あり，この問題がはっきり すれば，われわれは大いに協力するということに なった，日赤の方には，まことに相済まぬが，ご 研究を打願いしたい。

\section{発言 福岡県赤十字血液センター 吉成 意之}

赤十字血液センターは採血のみで, 配給機構を まだ整備していない。現在は, 従来の血液配給業 者のルートに乗せて, 献血の血液が円滑に広くか つ迅速に配給されるように心がけている. 福岡赤 十字病院には直配しているが，4月には 214本配 給している. 九大病院にはミドリ十字を経て 427 本, 久大病院と福岡南部の病院へは和光堂を経て 1139本, 福岡市内の病院その他へは, ミドリ十字 を経て28本, 九州血銀を経て 252本, 化血研を経 て 104本, 心蔵手術のため八幡厚生年金病院へ直 接に42本，その他 3 本を配給している。これらの 業者にはすべて配給先の病院名・診療所名・患者 氏名と血液本数を報告して貪っている。午の病院 数は 200 以上となっている.

献血の血液の性質上，もっと公共性をもった配 給機構の出現が待望される. 日赤自らもこれを 用意しょうと努力している.

\section{発言熊本大学吉永外科 中村 良昭}

私は外科医の立場から 2 つ問題点を述べたい と思います，その 1 つは, 輸血万能主義に対する 反省であり，まず術中出血量を少くするよらに努 力する一方, 輸血の必要性, 貧血の病態生理をよ く認識したらえで，血液を使うようにすることが 必要だと思います。

その 2 は, 献血制度の推進は理想ですが, 献血 にも幾多の問題点がある現在, 外科医としては, 手術に当面したさい，特定の対象に対する供血す なわち預血をすすめるべきで, 預血の推進は外科 医の義務であることを強調したいと思います． 


\section{第43回日本輸血学会関東地方会}

\section{日時 昭和 41 年 6 月 3 日 (金) 午後 3 時- 5 時 場所 昭和大学 \\ 当番幹事 \\ 常任幹事 \\ 昭和大学第 2 外科 \\ 東京女子医大外科 榊原仟 \\ 演題}

1. 冷凍血液 追加
東大第 2 外科 三浦 健 東邦大第 1 外科 隅田 幸男
2. 血液不足とその対策

$\begin{array}{rlr}\text { 東京国立第 } 1 \text { 病院 } & \text { 鳥居 } & \text { 有人 } \\ \text { 東大輸血部 } & \text { 二之宮景光 } \\ \text { 慶大外科 } & \text { 井上 } & \text { 正 } \\ \text { 慈大第 } 1 \text { 外科 } & \text { 山崎 } & \text { 順啓 } \\ \text { 厚生省薬務局 } & \text { 本田 } & \text { 正 } \\ \text { 東京厚生年金病院 } & \text { 東 陽一 }\end{array}$

\section{冷凍血液}

東大医学部第 2 外科 三浦 健

現在の $4{ }^{\circ} \mathrm{C}$ に打けるA C D 血保存法では 3 週間 しか血液が保存できないため, 保存血は需要と供 給のコントロールが困難で，著しく不足すること もあれば，またある時は需要が少なくて余った期 限切れの血液が大量に廃棄されることもある。も し赤血球をー $80^{\circ} \mathrm{C}$ の超低温に凍結するとすべての 代謝作用は完全に停止して血球細胞は生きたまま 数年にわたる長期保存を行ならことが可能であ る. 従って保存血の期限切れの心配もなく, 需要 と供給のアンバランスに困ることもなくなる。ま た自分の血を“預血”して氺いて必要な時にいつ でも凍結保存した自分の血液を解凍して使らとい ら“自己輸血”歹可能になってくる.さらに Rh マイナスのような, 珍しい型の血液も常時保存し て扣いて緊急の需要に応ずることも可能である.

しかし血液の涷結保存は $4{ }^{\circ} \mathrm{C}$ での冷蔵保存に比 べると決して簡単ではない。いきなり赤血球を凍 結すると赤血球の細胞膜が破壊されて溶血を扣こ すので, 凍結する前に凍害防止剂を適当な濃度に 添加しなければならない，細胞を凍結すると細胞 内の水の分子が水素結合で結合して氷の結晶を形 成するが，このさい細胞内の溶質はこのような型
の静電的結合には参加しないで氷の結晶構造から はみだしてしまう．その結果溶質は不凍水の中に 非常に濃縮されて集まり, 著るしい滲透圧の上㫒 をきたす。この渗透王の上昇が細胞凍結時の細胞 破壊の最も大きな原因と考只られて和る。ところ が凍㲅方止剤は水分子と強力な水素結合あるいは 共軛結合を抗こす能力があり，水分子と強く結 びっくことによって水分子が氷相にとりこまれる のを防ぎ, 凍結中の溶質の濃縮を最少限にくい止 める能力を有している.今日凍害防止剤としては Glycerol DMSO, などが知られており, 臨床的に は主として Glycerol が用いられている。

さて，このょうにして凍結保存した血球を解凍 して輸血するにあたっては添加した凍害防止剂を 除去しなければならない，従来は Cohn のFractionator を用いて血球と凍害防止剤を分離する方 法が 1 部で試みられていた。ところがハーバード 大学のハギンス講師は第13回日本輸血学会の招待 講演で述べた如く，ブドウ糖液で赤血球を洗う時 に抗こる赤血球の可逆的凝集反応を利用して簡 単に凍害防止剤を分離する装置を考案した。これ はブドウ糖液の $\mathrm{pH}$ H゙低い為に血球表面のリポプロ テインと血浆中のガンマグロブリンが結合し， さらにブドウ糖液のイオン濃度が低いためガンマ グロブリンとガンマグロブリンの結合がおこり, 結局, 赤血球リポプロテイン-ガンマグロブリン 
-ガンマグロブリン-赤血球リポプロテインの 結合 でおこる血球の凝集反応を利用したものである. このハギンスの血球凝集装置を用いると遠心沈澱 を行なわなくても速かに，簡単に Glycerol を洗 ったブドウ糖液と血球を分離することが可能で あり，臨床応用の上で冷凍血液の再生処理が著 しく簡単になった。

以上の方法で再生した冷凍血球は溶血も少く, 輸血後24時間で87-95\%の血球細胞が生きており， 赤血球寿命も半減期平均 30.5 日で普通の A C D 血 と同じ位長い。なお大量のブドウ糖液で血球を洗 らため, 再生した冷凍血球はＡＣＤ血に比べて血 中カリウムは極めて低く, 腎機能の悪い患者, 心 不全の患者にも安心して使用できる。また発熱， らる光, 萇麻疹等の白血球免疫抗体や血小板免疫 抗体による副作用や異種蛋白によるアレルギー反 応は全くおこらない。また血清肝炎ビールスも殆 んど洗い流されてしまうものと思われ。ボストン に拈けるハギンス・三浦の経験では2250単位の輸
血例の中からは血清肝炎は 1 例も発生していな い.

以上の如く, 冷凍血液には種々の利点があり, アメリカでは既にハーバード大学のマサチニーセ ツッ, ゼネラルホスピタルやボストンの海軍病院 をはじめ各地で冷凍血液は臨床に使われており， またベトナムの第一線でも冷凍血液が大量に使用 されている．ただ血球の凍結保存に当っては高価 な冷凍血液処理装置や，ディープフリーザーを必 要とし, 保存用のプラステイックバッグや大量の ブドゥ糖液を消費するため血液の価格がかなり高 価となるのが欠点である。

近時わが国でも，著しい血液の不足に直面して 血液の長期保存の問題が注目され，また血清肝炎 の防止はわれわれの極めて重要な課題となって いるが，アメリカにおける冷凍血液の臨床応用の すぐれた効果をみるにつけても，今後この方面の 研究は極めて重要かつ意義あるものと思われる。 